\title{
The Effect of Learning Motivation on Learning Independence and Learning Outcomes of Students in the Package C Equivalence Program
}

\author{
Moh Ghoizi Eriyanto', M.V. Roesminingsih'2, Soedjarwo ${ }^{3}$, Ivan Kusuma Soeherman ${ }^{4}$ \\ 1,2,3 State University of Surabaya, Surabaya, Indonesia \\ ${ }^{4}$ National Cheng Kung University, Tainan, Taiwan
}

\begin{tabular}{|c|c|}
\hline 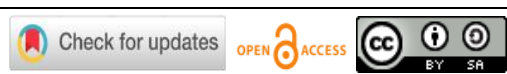 & DOI : https://doi.org/10.46245/ijorer.v2i4.122 \\
\hline Secti & CT \\
\hline & \multirow{10}{*}{$\begin{array}{l}\text { The purposes of this research are (1) Knowing the effect of learning motivation } \\
\text { on the learning independence of students in the Package C Equivalence } \\
\text { Program in; (2) Knowing the effect of learning motivation on student learning } \\
\text { outcomes of the Package C Equivalence Program students. This research uses } \\
\text { quantitative research with correlational methods. The number of research } \\
\text { samples was } 120 \text { students. There are two variables in this research, namely the } \\
\text { independent variable and the dependent variable. The independent variable is } \\
\text { the treatment of this study, namely learning motivation. The dependent } \\
\text { variable is learning independence and learning outcomes. The data collection } \\
\text { techniques used were questionnaires and tests. Questionnaires are used to } \\
\text { determine the results of learning motivation and learning independence, while } \\
\text { tests are used to determine learning outcomes. Hypothesis test data analysis } \\
\text { technique is simple linear regression analysis. The results and analysis of } \\
\text { research data were obtained as follows: (1) There was an effect of learning } \\
\text { motivation on the learning independence of students in the Package C } \\
\text { Equality Program. }\end{array}$} \\
\hline & \\
\hline & \\
\hline & \\
\hline & \\
\hline & \\
\hline & \\
\hline & \\
\hline & \\
\hline 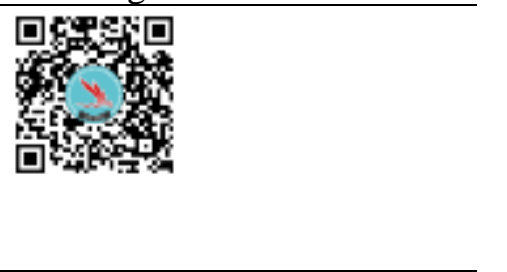 & \\
\hline
\end{tabular}

\section{INTRODUCTION}

The non-package $\mathrm{C}$ human program as an educational institution has a very big role and need in preparing reliable resources and ready to face challenges in the future. Through educational institutions a person will get a variety of knowledge, experience and skills. The definition above is known that the orientation of education is to mature and mature students, so that they will become independent personal figures in dealing with various problems that arise both during the educational process and those found in everyday life. Aisyiyah (2012) said that in order to become a quality human being, a person must continuously improve his knowledge and skills in accordance with the demands of the times, in other words, he needs to learn throughout his life or become a life long learner.

The low quality of Indonesia's human resources is one indicator that national education has not been able to produce a generation that is independent in learning. Learning will be able to give a change in a person because learning is to find out how far changes that occur in a person who follows the process learning in lectures. Someone who goes through the learning process there will definitely be an independent soul, because by learning can change attitudes can stand alone. Change of attitude someone where that someone can stand alone without depending on others in the learning process This is what is called independence study. In other words, the learning independence of Indonesian students still needs to be improved. Independent learning is not a talent or innate that is brought from birth, the independence of learning must be grown and developed in the educational process. Syah (2015) says that learning almost always gets a large place in education various disciplines related to educational efforts. It shows that the success or failure of an educational goal will depend on a lot to how 
The Effect of Learning Motivation on Learning Independence and Learning Outcomes of Students in the Package C Equivalence Program

the learning process experienced by students. Therefore, the package $C$ program in the Tanjunganom sub-district must pay attention to environmental conditions that are conducive to developing independent learning for students.

Slameto (2015) argues that a person's view of learning will affect his actions related to learning and everyone has a different view of learning. Independent learning is closely related to learning motivation (Safaruddin et al., 2020). In a study conducted by Isnawati and Samian (2015), it can be seen that the contribution of learning motivation to learning independence is $15.9 \%$. Strong motivation to achieve the goals to be achieved is needed in building intelligence. If there is strong motivation, it will create an attitude of independence from within students. Tutors do play a role in achieving student learning outcomes, but actually students are in control of their learning outcomes. Efforts can be made to achieve satisfactory learning outcomes, one of which is by growing and developing independence that is driven by the motivation to learn. Learning outcomes are the results achieved by individuals after experiencing a learning process. Learning outcomes are obtained at the end of the learning process and are related to the ability of students to absorb or understand a material that has been taught. There have been many empirical studies proving the many factors that influence learning outcomes, one of which is learning motivation which relate with student.

Learning motivation is also a driving factor for student learning outcomes because learning motivation itself is a mental factor that drives learning. Motivation contains the desire to activate, move, channel, direct the attitudes and behavior of individual learning (Dimyati and Mudjiono, 2013: 80). A study conducted by Atmawati (2013) revealed that learning motivation has a positive and partially significant effect on learning outcomes by $12.30 \%$. The need that occurs when the individual has an imbalance between what is owned and what is expected, the expectations referred to here are the needs and achievements of each person.

The results of the pre-orientation pre-study conducted in 4 Centers for Community Learning Activities Tanjunganom District, researchers saw that students' learning independence was still less than optimal, when learning more outside the classroom. The independence possessed by students who are different from others, students who have learning independence and vice versa students who have learning independence. This can be seen from the enthusiasm and attention of students in participating in learning. Based on the direct observation of the researcher during the learning process, the students only listened to the explanation given by the tutor. Students' attention to learning is still lacking, which is marked by students who are still busy with their classmates and their own activities. It was also found that students in learning only listened to explanations and saw examples given by the tutor, students were only silent when asking questions and students were also silent when the tutor asked. In addition, when students complain when what they do is not up to what they want. Only a few students actually look for books or ask their next door friends and tutors to find out what next steps to take. This shows that students have the initiative and self-confidence to find out what is not known so that they can be independent and learn independently from students. After conducting interviews with tutors, the learning outcomes achieved by the Package C Equivalence Program students in Tanjunganom District are still not optimal. Based on the above background, the authors are interested in conducting 
The Effect of Learning Motivation on Learning Independence and Learning Outcomes of Students in the Package C Equivalence Program

research with the title "The Effect of Learning Motivation on Learning Independence and Learning Outcomes of Students in the Package C Equivalence Program.

\section{RESEARCH METHOD}

\section{General Background}

This research uses quantitative research with correlational method. Quantitative research method is one type of research whose specifications are systematic, wellplanned and clearly structured from the beginning to the making of the research design. According to Sugiyono (2013), quantitative research methods can be interpreted as research methods based on the philosophy of positivism, used to examine certain populations or samples, sampling techniques are generally carried out randomly, data collection uses research instruments, data analysis is quantitative or statistics with the aim of testing established hypotheses.

This research uses quantitative research with correlational method. Azwar (2016) revealed that correlational research aims to investigate the extent to which variations in a variable are related to variations in one or more other variables, based on the correlation coefficient. From this research can obtain information about the level of the relationship that occurs, not about the effect of one variable on another variable. According to Arikunto (2013: 4) research correlational is research conducted by researchers to determine the degree of relationship between two or more variables, without making changes, addition or manipulation of existing data. In this study, students were given a motivational questionnaire, from the results of the questionnaire, high and low student motivation results. Furthermore, students are given a learning independence questionnaire.

\section{Sample / Participants / Group}

The population in this study were 4 PKBM (Community Learning Activity Centers) in Tanjunganom District, Nganjuk Regency, namely PKBM Harapan Jaya, PKBM Nurul Jadid, PKBM Nurul Jamal, PKBM Tri Bakti. Gay in Mahmud (2011: 159) argues that the minimum acceptable sample size based on the research method used for the correlational method is at least 30 subjects. Based on this theory, from each PKBM (Center for Community Learning Activities), the researchers took a sample of 30 students. So the total number of samples is 120 students.

\section{Instrument and Procedures}

Based on several predetermined variables, then examine these variables through several theories that support, and provide operational definitions of variables. Then determine the indicators to be measured. The instrument is students' learning motivation which contains 16 statements with 4 answer choices, namely strongly agree, agree, disagree, and strongly disagree. This study was conducted to analyze and investigate the relationship between two variables, namely learning motivation on learning independence and learning motivation on learning outcomes. 
The Effect of Learning Motivation on Learning Independence and Learning Outcomes of Students in the Package C Equivalence Program

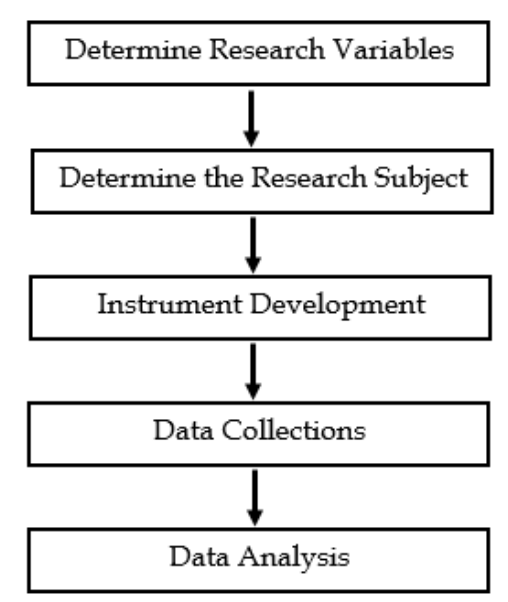

Figure 1. Flowchart of research procedures.

This research start from determine research variables both independent and dependent variables, then determining research subjects involving 120 respondents, followed by developing instruments and data collection, then the data that has been obtained analyzed based on descriptive statistic and inferential statistic and involves correlation analysis. The procedure carried out outline following flow chart in Figure 1.

Table 1. Learning motivation questionnaire instrument.

\begin{tabular}{|c|c|c|}
\hline Variabel & Indikator & No Item \\
\hline \multirow{4}{*}{ Attention } & - Provide novelty and surprise & 1 \\
\hline & - Stimulate curiosity by posing questions or problems to solve & 2 \\
\hline & - Incorporate a range of methods and media to meet students' & \\
\hline & varying needs & 3 \\
\hline \multirow{3}{*}{ Relevance } & $\begin{array}{l}\text { - Present objectives and useful purpose of instruction and } \\
\text { specific methods for successful achievement }\end{array}$ & 4 \\
\hline & - Match objectives to student needs and motives & 5 \\
\hline & - Present content in ways that are understandable and that & 6 \\
\hline \multirow{4}{*}{ Confidence } & & 7 \\
\hline & requirements and assessment criteria & $\gamma$ \\
\hline & $\begin{array}{l}\text { - Provide challenging and meaningful opportunities for } \\
\text { successful learning }\end{array}$ & 8 \\
\hline & - Link learning success to student' personal effort and ability & 9 \\
\hline \multirow{3}{*}{ Satisfaction } & $\begin{array}{l}\text { - Encourange and support intrinsic enjoyment of the learning } \\
\text { experience }\end{array}$ & 10 \\
\hline & - Provide positive reincement and motivational feedback & 11 \\
\hline & - Maintain consistent standards and consequences for succes & 12 \\
\hline
\end{tabular}

Table 2. Learning independence questionnaire instrument

\begin{tabular}{cccc}
\hline & Aspect & Indicator & Nom. Item \\
\hline \multirow{2}{*}{1} & \multirow{2}{*}{ Have own initiative } & Able to direct himself & 1 \\
& & Have the courage to act & 2
\end{tabular}


The Effect of Learning Motivation on Learning Independence and Learning Outcomes of Students in the Package C Equivalence Program

\begin{tabular}{|c|c|c|c|}
\hline & Aspect & Indicator & Nom. Item \\
\hline \multirow{2}{*}{2} & Formulate learning & Have a future orientation & 3 \\
\hline & objectives & Have your own desire to learn & 4 \\
\hline \multirow{2}{*}{3} & Diaonosing study goals & Determining learning speed & 5 \\
\hline & Diagnosing stuay goais & Organizing study goals & 6 \\
\hline \multirow{2}{*}{4} & Identify learning & $\begin{array}{c}\text { Trying to find reference sources in } \\
\text { learning }\end{array}$ & 7 \\
\hline & resources or literature & $\begin{array}{l}\text { Able to determine the material to be } \\
\text { studied }\end{array}$ & 8 \\
\hline \multirow{2}{*}{5} & $\begin{array}{l}\text { Selecting and } \\
\text { implementing }\end{array}$ & Able to develop learning steps & 9 \\
\hline & $\begin{array}{l}\text { appropriate learning } \\
\text { strategies }\end{array}$ & Understand how to learn & 10 \\
\hline \multirow[b]{2}{*}{6} & Evaluating learning & Play a role in evaluating learning & 11 \\
\hline & outcomes & $\begin{array}{l}\text { Observing the increase and decrease in } \\
\text { learning outcomes }\end{array}$ & 12 \\
\hline
\end{tabular}

(Knowles et al, 2005)

\section{Data Analysis}

The normality test in this study was taken from the test scores prior to the provision of learning motivation to students. The researcher used the Kolmogrov-Smirnov (KS) test with the condition that if the asymp.Sig ( 2 tailed) value obtained $>0.05$, then the sample came from a normally distributed population, but if the asymp.Sig ( 2 tailed) value obtained $<0.05$, then the sample does not come from a normally distributed population (Sugiyono, 2013). Statistics is a science that consists of theories and methods which are branches of applied mathematics and talks about how to collect data, how to summarize data, process and present data, how to draw conclusions from the results of the analysis, and how to make decisions within certain risk limits based on strategies there is. The statistical method that is widely used in analyze research results and observations is the analysis of variance (ANOVA) method. One type of ANOVA analysis that will be used in this study is one-way ANOVA analysis or also known as one-way ANOVA (Fitrayudha, 2020). So that in this study the researchers in the calculation will use the SPSS Version 23 program. Testing on SPSS using the Test for Linearity, the basis for decision making using ANOVA output at a significance level of $=0.05$. If $<0.05$ then the relationship between the two variables is linear and if $>0.05$ then the relationship is not linear.

\section{RESULTS AND DISCUSSION}

The data collection technique used is a questionnaire. The data analysis technique of hypothesis testing is simple linear regression analysis. Prerequisite test using normality test and linearity test. Based on the results of the normality test in table 1, it is known that the significance value is 0.168 or $0.168>0.05$. So that researchers can conclude that the sample is normally distributed. So that it can be continued on the next prerequisite test, namely the linearity test. 
The Effect of Learning Motivation on Learning Independence and Learning Outcomes of Students in the Package C Equivalence Program

\begin{tabular}{|ll|r|}
\hline \multicolumn{2}{|c|}{ One-Sample Kolmogorov-Smirnov Test } \\
\hline $\mathrm{N}$ & & Normalitas \\
Normal Parameters $\mathrm{a}, \mathrm{b}$ & Mean & 120 \\
& Std. Deviation & 62.6917 \\
& 9.77804 \\
Most Extreme Differences & Absolute & .269 \\
& Positive & .143 \\
& Negative & -.269 \\
Test Statistic & & .269 \\
Asymp. Sig. (2-tailed) & & $.168^{\mathrm{c}}$ \\
\hline
\end{tabular}
a. Test distribution is Normal.
b. Calculated from data.
c. Lilliefors Significance Correction.

Figure 2. Normality Test Result

The linearity test is usually used as a prerequisite in correlation or linear regression analysis. Testing can be done with the Statistical Product and Service Solution (SPSS) software, using a test for linearity at a significance level of 0.05 .

\begin{tabular}{|l|r|r|r|c|c|}
\hline Model & Sum of Squares & \multicolumn{1}{|c|}{ df } & Mean Square & \multicolumn{1}{c|}{ F } & \multicolumn{1}{c|}{ Sig. } \\
\hline Regression & 5032.849 & 1 & 5032.849 & 1555.696 & $.000^{\mathrm{b}}$ \\
Residual & 381.743 & 118 & 3.235 & & \\
Total & 5414.592 & 119 & & & \\
\hline
\end{tabular}
a. Dependent Variable: Motivasi
b. Predictors: (Constant), Kemandirian

Figure 3. ANOVA Result of Learning Motivation on Independent Learning

\begin{tabular}{|l|r|r|r|c|c|}
\hline Model & Sum of Squares & df & Mean Square & F & \multicolumn{1}{c|}{ Sig. } \\
\hline Regression & 5041.567 & 1 & 5041.567 & 1594.814 & $.000^{\mathrm{b}}$ \\
Residual & 373.025 & 118 & 3.161 & & \\
Total & 5414.592 & 119 & & & \\
\hline
\end{tabular}
a. Dependent Variable: Motivasi
b. Predictors: (Constant), Hasil Belajar

Figure 4. ANOVA Result of Learning Motivation on Learning Outcomes

Based on the results of the linearity test in figure 3, it is known that the calculated $\mathrm{F}$ value is 1555,696 with a significance level or of $0.000<0.05$, then learning motivation can be used to predict the variable of learning independence. Likewise with the results of the linearity test in table 3 , it is known that the calculated F value is 1594,814 with a 
The Effect of Learning Motivation on Learning Independence and Learning Outcomes of Students in the Package C Equivalence Program

significance level of $0.000<0.05$, then learning motivation can be used to predict learning outcomes variables.

Next, to determine the effect of learning motivation on students' learning independence, a simple linear regression statistical test will be used. Statistical calculations for linear regression analysis were carried out with the help of the SPSS program. From the results of the analysis carried out, the following results are obtained:

\begin{tabular}{|l|r|r|r|r|r|}
\hline \multirow{2}{*}{} & \multicolumn{2}{|c|}{$\begin{array}{c}\text { Unstandardized } \\
\text { Coefficients }\end{array}$} & $\begin{array}{c}\text { Standardized } \\
\text { Coefficients }\end{array}$ & & \\
\cline { 2 - 6 } Mode1 & $\mathrm{B}$ & Std. Error & \multicolumn{1}{c|}{ Beta } & \multicolumn{1}{c|}{$\mathrm{r}_{\times \mathrm{y}}$} & \multicolumn{1}{c|}{ Sig. } \\
\hline 1 (Constant) & 8.782 & .956 & & 9.183 & .000 \\
Independence & 1.052 & .027 & .964 & 39.442 & .000 \\
\hline
\end{tabular}

a. Dependent Variable: Motivation

Figure 5. The result of the coefficients of learning motivation on learning independence

To determine the effect of learning motivation on student learning outcomes, a simple linear regression statistical test will be used. Statistical calculations for linear regression analysis were carried out with the help of the SPSS program. From the results of the analysis carried out, the following results are obtained:

\begin{tabular}{|c|c|c|c|c|c|}
\hline \multicolumn{6}{|c|}{ Coefficients $\mathrm{s}^{\mathrm{a}}$} \\
\hline \multirow[b]{2}{*}{ Model } & \multicolumn{2}{|c|}{ Unstandardized Coefficients } & \multirow{2}{*}{$\begin{array}{c}\text { Standardized } \\
\text { Coefficients } \\
\text { Beta } \\
\end{array}$} & \multirow[b]{2}{*}{$r_{x y}$} & \multirow[b]{2}{*}{ Sig. } \\
\hline & $\mathrm{B}$ & Std. Error & & & \\
\hline 1 (Constant) & -5.116 & 1.289 & & -3.969 & .000 \\
\hline $\begin{array}{l}\text { Learning } \\
\text { Outcomes }\end{array}$ & .619 & .016 & .965 & 39.935 & .000 \\
\hline
\end{tabular}

a. Dependent Variable: Motivation

Figure 6. The result of the coefficients of learning motivation on learning outcomes

Based on the calculation of the data in table 5, the significance value based on the Sig column is 0.000 or $<0.05(0.000<0.05)$, which means the Alternative Hypothesis is accepted. Thus it can be concluded that there is a real (significant) influence on learning motivation on student learning outcomes.

Based on the results of the linear analysis analysis test calculation, the significance value is 0.000 or $<0.05(0.000<0.05)$. From these calculations, it can be concluded that there is an influence, which means that the higher the motivation to learn, the higher the learning independence of the students of the Package C Equivalence Program in Tanjunganom District, Nganjuk Regency. This is in line with research conducted by Aisyiyah (2013), the results of the study indicate that there is a significant influence of 
The Effect of Learning Motivation on Learning Independence and Learning Outcomes of Students in the Package C Equivalence Program

motivation on student learning independence. The results of the study show a positive and significant influence between motivation on learning independence.

Learning motivation is a spirit, passion or encouragement that arises from within students so that they can learn to be better. The growth of a motivation in learning will make someone have the desire to be able to be better in learning, one of which is being independent. someone who is motivated in learning means that it indicates he has a desire to be achieved. In the research of Ariyani (2012) concluded that there is a positive influence of learning motivation on learning independence. the higher the motivation in learning, the higher the learning independence, and vice versa if the motivation is low, the level of learning independence will also be low.

This drive from within a person is what makes a person want to be independent. so that it can be concluded that the motivation in learning will foster a spirit of independence in the learning process. Learning motivation has a role as an encouragement to someone who is learning to make changes in behavior. Slameto (2015: 2) argues that a person's view of learning will affect his actions related to learning and everyone has a different view of learning. Learning will succeed optimally if it is done with full independence. Independence includes the behavior of being able to take the initiative, being able to overcome obstacles or problems, having self-confidence, and being able to do things without the help of others. People who behave independently have a desire to do everything for themselves and are able to solve problems faced by themselves without having to expect help from others.

Hamalik (2012) concluded that based on the understanding and analysis of motivation, basically motivation has two properties, namely intrinsic and extrinsic. Intrinsic motivation which is often called "pure motivation" is the motivation involved in learning situations that come from the needs and goals of the students themselves. This motivation arises without any outside influence. while extrinsic motivation is motivation caused by factors from outside the learning situation. This motivation is needed in schools because not all learning in schools can attract interest or according to the needs of students.

Based on the results of the linear analysis analysis test calculation, the significance value is 0.000 or $<0.05(0.000<0.05)$. From these calculations, it can be concluded that there is an influence, meaning that the higher the motivation to learn, the higher the learning outcomes of students in the Package C Equivalence Program in Tanjunganom District, Nganjuk Regency. This is in line with research conducted by Nurmala et al (2014), the results of the study show that learning motivation affects learning outcomes. The results of the study concluded that there was a positive influence between students' learning motivation and learning outcomes.

According to Ainurahman (2012) student learning activities that are driven by learning motivation are a sign that students already have self-awareness to study seriously. One of the real things that can be seen is that students who have high learning motivation and learning activities will get good results as well. Interest and motivation to learn are two psychological factors that have been empirically proven to have a significant influence on students' academic achievement at school (Kpolovie et al, 2014). Students who have high learning interest and motivation are usually characterized by good academic grades, have structured study habits, have a good understanding of each reading (Silvia, 2012, in Black and Allen, 2016), have high self- 
The Effect of Learning Motivation on Learning Independence and Learning Outcomes of Students in the Package C Equivalence Program

efficacy, and have high learning performance (Tang and Reynolds, 1993, in Howard et al, 2014). As for students who have low interest and motivation to learn, usually have a tendency to withdraw, do not attend school, drop out of school, have relatively high anxiety, and have low academic results (Prospero and Vohra, 2007 in Sturges et al, 2016).

Petri (1981) as quoted by Cetin (2015) reveals that learning motivation is a nurturing or guiding behavior and innate strength of students. As a concept, learning motivation is defined as an internal factor that has four components, namely opportunities for success, fear of failure, interests, and challenges (Margarete and Hilbert, 2013). McCoach and Siegle (2003), in Garn and Jolly (2014) say that learning motivation is one of the factors that can distinguish students who maximize their learning potential from students who lack academic achievement. Apart from being one of the factors that determine the direction of attitudes, the amount of willingness, and persistence of student behavior (Keller, 2016), learning motivation also refers to expectations and values, where Expectations indicate that students are able to complete the assigned tasks and grades indicate strong student beliefs to succeed in learning (Riconscente, 2014). Based on the explanation of the definition of learning motivation above, it can be concluded that learning motivation is a power in students that encourages them to be willing and diligent in learning, to make the best and directed efforts in the learning process to achieve the best results which are goals that are owned and maintained during the learning process. take place.

As one of the benchmarks to measure success learning process, learning outcomes reflect the results of the learning process shows the extent to which students, teachers, learning processes, and educational institutions have achieved the educational goals that have been determined (Kpolovie et al, 2014). Learning outcomes are also the result of the completion of the learning process, where through In learning, students can know, understand, and can apply what is studied (O'Farrell and Lahiff, 2014). Hamdan and Khader (2015) explain that learning outcomes are the basis for measuring and reporting student academic achievement and is a key in develop further learning designs that are more effective that have alignment between what students will learn and how they will be assessed. As a final product of the learning process, learning outcomes are assessed as show what students already know and develop, Knaack (2015). Learning's outcomes It is also a report of what the learner got after finishing the process learning (Popenici and Millar, 2015). Based on the explanation of the definition of learning outcomes, it can be concluded that the results of learning is the accumulation of learning gained by students during the learning process learning. Learning outcomes are educational goals that are embodied in the process learning so that students can know, understand, and apply the knowledge he received.

Changes in learning outcomes can be observed, proven, and measurable in abilities or achievements experienced by students as a result of learning experiences (Németh and Long, 2012) which is built through the learning process (Singh et al, 2015). Learning motivation is an absolute requirement for learning and holding important role in providing passion or enthusiasm for learning. Motivation to learn is not only a driving force to achieve good results but contains effort to achieve learning goals (Puspitasari, 2013). So it can be said that motivation will always determine the intensity of the learning effort for students so that student learning outcomes will increase (Palupi, 
The Effect of Learning Motivation on Learning Independence and Learning Outcomes of Students in the Package C Equivalence Program

2014). Learning motivation has a big role in the success of a student. Learning outcomes will be optimal if there is motivation to learn. The more precise the motivation given, the better the learning outcomes. Thus, motivation always determines the intensity of the learning effort for students (Bakar, 2014).

\section{CONCLUSIONS}

Motivation refers to the internal conditions that encourage, direct and maintain one's behavior. This motivation plays a very important role in the learning process. The function of the first motivation is to encourage students to act, so as a mover or motor that releases energy. The second function is to determine the direction of action, namely towards the goal to be achieved. Thus, motivation can provide direction and activities that must be carried out in accordance with the objectives. The third function is useful for selecting actions, namely determining what actions must be carried out to achieve the goal, by leaving the actions that are not useful. The existence of a learning motivation will also encourage the emergence of student learning independence, because by having a motivation a student is driven by the spirit and passion to change attitudes to become independent. Some of the reasons why children cannot learn independently, one of which is because there is no motivation in learning, without motivation, independence will not be created. Learning outcomes cannot be separated from the learning process undertaken by students in teaching and learning activities. From the tutor's point of view, teaching ends with an evaluation process of learning outcomes, while from the students' perspective, learning outcomes are the results achieved by students. Motivation is a factor that has a large enough influence on learning outcomes. learning motivation is the tendency of students to carry out learning activities that are driven by a desire to achieve the best possible learning outcomes. Learning motivation will encourage the spirit of learning in students and vice versa lack of motivation to learn will weaken the spirit of learning which will also affect student learning outcomes. A student who learns without motivation will not get maximum results, it can be seen from the learning activities of students in the classroom while attending lessons. Student learning activities are very important in determining success in learning. In learning activities, students are required to actively participate in the learning process, which can be seen from the seriousness of paying attention to the tutor's explanation, asking questions about things that they do not understand or their persistence in doing the tasks given by the tutor. Active learning activities will have a positive influence on students. Therefore, efforts in realizing creative and innovative students, tutors are the spearhead in achieving student success and are expected to provide learning motivation for students, because the success of students in learning is strongly influenced by the learning motivation provided by the tutor. The existence of a strong learning motivation in learning activities will create a conducive and interactive atmosphere in learning.

\section{REFERENCES}

Ainurahman. (2012). Belajar dan pembelajaran. Bandung: Alfabeta.

Aisyiyah, S. (2012). Kemandirian belajar dan hubungannya dengan lingkungan belajar serta motivasi belajar siswa. Jurnal Ilmiah Inovasi, 12(3), 38-47. 
The Effect of Learning Motivation on Learning Independence and Learning Outcomes of Students in the Package C Equivalence Program

Arikunto, S. (2013). Prosedur penelitian suatu pendekatan praktik (edisi revisi). Jakarta: PT. Rineka Cipta

Ariyani, P. D. (2012). Pengaruh motivasi belajar dan cara belajar terhadap kemandirian belajar pada siswa kelas X SMA Negeri 2 Ampel tahun ajaran 2011/2012. Skripsi. Universitas Sebelas Maret

Atmawati, I. N. (2013). Pengaruh motivasi belajar, kesiapan belajar, dan lingkungan keluarga terhadap hasil belajar akuntansi siswa kelas XI akuntansi SMK teuku umar semarang tahun ajaran 2012/2013. Skripsi. Universitas Negeri Semarang.

Azwar, S. 2016. Metode penelitian. Yogyakarta: Pustaka Pelajar

Bakar, R. (2014). The effect of learning motivation on student's productive competencies in vocational high school, West Sumatra. International Journal of Asian Social Science, $4(6), 722-732$.

Black, S., \& Allen, J. D. (2016). Part 1: Foster intrinsic motivation. The Reference Librarian, 58(1), 1-16. doi.org/10.1080/02763877.2016.1200515

Cetin, B. (2015). Academic motivation and self-regulated learning in predicting academic achievement in college. Journal of International Education Research, 11(2), 95-106. doi.org/10.19030/jier.v11i2.9190

Dimyati \& Mudjiono. (2013). Belajar dan pembelajaran. Bandung: Rineka Cipta

Fitrayudha, A., Fajrin, A., \& Anshari, B. (2020). Analisis sifat mekanis komposit polyester sisal menggunakan metode anova. Bina Patria, 14(7), 2817-1824. doi.org/10.33758/mbi.v14i7.489

Garn, A. C., \& Jolly, J. L. (2014). High ability students voice on learning motivation. Journal of Advanced Academics, 25(1), 7-24. doi.org/10.1177/1932202X13513262

Hamalik, O. (2012). Kurikulum dan pembelajaran. Jakarta: Bumi Aksara

Hamdan, T. A., \& Khader, F. (2015). Alignment of intended learning outcomes with quellmalz taxonomy and assessment practices in early childhood education courses. International Journal of Humanities and Social Science, 5(3), 130-137.

Howard, L. W., Tang, T. L. P., \& Austin, M. J. (2014). Teaching critical thinking skills: ability, motivation, intervention, and the pygmalion effect. Journal of Business Ethics, 128(1), 133-147. doi.org/10.1007/s10551-014-2084-0

Isnawati, N., \& Samian. (2015). Kemandirian belajar ditinjau dari kreativitas belajar dan motivasi belajar mahasiswa. Jurnal Pendidikan Ilmu Sosial, 25(1), 128-144.

Keller, J. M. (2016). Motivation, learning, and technology: Applying the arcs-v motivation model. Participatory Educational Research, 3(2), 1-13. doi.org/10.17275/PER.16.06.3.2

Knaack, L. (2015). Enhancing your programs and courses through aligned learning outcomes. Vancouver: Vancouver Island University.

Knowles, M. S., Holton, E. F., Swanson, R. A., \& Holton, E. (2005). The adult learner: The definitive classic in adult education and human resource development. Elsevier: Business \& Economics.

Kpolovie, P. J., Joe, A. I., \& Okoto, T. (2014). Academic achievement prediction: role of interest in learning and attitude towards school. International Journal of Humanities Social Sciences and Education, 1(11), 73-100.

Mahmud. 2011. Metode penelitian pendidikan. Bandung: Pustaka Setia. 
The Effect of Learning Motivation on Learning Independence and Learning Outcomes of Students in the Package C Equivalence Program

Margarete, I., \& Hilbert, T. S. (2013). The role of motivation, cognition, and conscientiousness for academic achievement. International Journal of Higher Education, 2(3), 69-80. doi.org/10.5430/ijhe.v2n3p69

Németh, J., \& Long, J. G. (2012). Assessing learning outcomes in US planning studio courses. Journal of Planning Education and Research, 32(4), 476-490. doi.org/10.1177/0739456X12453740

Nurmala, D. A. 2014. Pengaruh motivasi belajar dan aktivitas belajar terhadap hasil belajar akuntansi. Universitas Pendidikan Ganesha

O'Farrell, C., \& Lahiff, A. (2014). Writting learning outcomes: A guide for academics. Dublin: Trinity College Dublin.

Palupi, R. (2014). Hubungan antara motivasi belajar dan persepsi siswa terhadap kinerja guru dalam mengelola kegiatan belajar dengan hasil belajar IPA Siswa kelas VIII Di SMPN N 1 Pacitan. Jurnal Teknologi Pendidikan dan Pembelajaran, 2(2), 157-177.

Popenici, S., \& Millar, V. (2015). Writing learning outcomes: A practical guides for academics. Melbourne: Melbourne Centre for the Study of Higher Education.

Puspitasari, D. B. (2013). Hubungan antara persepsi terhadap iklim kelasdengan motivasi belajar siswa SMP negeri 1 bancak. Empathy, 1(1), 59-67

Riconscente, M. M. (2014). Effects of perceived teacher practices on latino high school student interest, self-efficacy, and achievement in mathematics. The Journal of Experimental Education, 82(1), 51-73. doi.org/10.1080/00220973.2013.813358

Safaruddin, S., Ibrahim, N., Juhaeni, J., Harmilawati, H., \& Qadrianti, L. (2020). The Effect of Project-Based Learning Assisted by Electronic Media on Learning Motivation and Science Process Skills. Journal of Innovation in Educational and Cultural Research, 1(1), 22-29. https:/ / doi.org/10.46843/jiecr.v1i1.5

Singh, A. K., Srivastava, S., \& Singh, D. (2015). Student engagement as the predictor of direct and indirect learning outcomes in the management education context. Metamorphosis, 14(2), 20-29.

Slameto. (2015). Belajar dan faktor-faktor yang mempengaruhi. Jakarta: Rineka Cipta.

Sturges, D., Maurer, T. W., Allen, D., Gatch, D. B., \& Shankar, P. (2016). Academic performance in human anatomy and physiology classes: A two years study of academic motivation and grade expectation. Advances Psychology Education, 40(1), 26-31. doi.org/10.1152/advan.00091.2015.

Sugiyono. (2013). Metode penelitian pendidikan pendekatan kuantitatif, kualitatif, dan RED. Bandung: Alfabeta.

Syah, M. (2015). Psikologi belajar. Jakarta: Rajawali Pers.

\footnotetext{
*Moh. Ghoizi Eriyanto, M.Pd.

Postgraduate Program Nonformal Education

State University of Surabaya

J1. Kampus Unesa Lidah Wetan Kota Surabaya

Email: moh.ghoizi.19003@mhs.unesa.ac.id

Prof. Dr. M.V. Roesminingsih, M.Pd.

Postgraduate Program Nonformal Education

State University of Surabaya

Jl. Kampus Unesa Lidah Wetan Kota Surabaya
} 
The Effect of Learning Motivation on Learning Independence and Learning Outcomes of Students in the Package C Equivalence Program

Email: roesminingsih@unesa.ac.id

\section{Dr. Soedjarwo, M.S.}

Postgraduate Program Nonformal Education

State University of Surabaya

Jl. Kampus Unesa Lidah Wetan Kota Surabaya

Email: soedjarwo@unesa.ac.id

\section{Ivan Kusuma Soeherman}

Postgraduate International Business

National Cheng Kung University, Taiwan

1 University Road, Tainan City, Taiwan, R.O.C. 70101

Email: ivankusuma389@gmail.com 